\title{
Estudio de la velocidad de corrosión de aceros embebidos en morteros de cemento sustituidos con residuo de catalizador de craqueo catalítico (FC3R)
}

\section{Corrosion rate of steel embedded in blended Portland and fluid catalytic cracking catalyst residue (FC3R) cement mortars}

\author{
E. Zornoza $(*)$, P. Garcés(**) y J. Payá(*)
}

Recepción/Received: 19-XII-06

Aceptación/Accepted: 13-XII-07

Publicado online/Online publishing: 1-XII-08

\section{RESUMEN}

En este trabajo se ha estudiado el nivel de corrosión de barras de acero embebidas en morteros de cemento Portland con relación agua/material cementante $(\mathrm{a} / \mathrm{mc})$ variable $(0,3-0,7)$, en los que parte del cemento $(0-20 \%)$ se sustituyó por catalizador de craqueo usado (FC3R). Las condiciones de conservación de las probetas elaboradas fueron las siguientes: distintas humedades relativas $(40,80$ y $100 \%)$ y dos concentraciones de $\mathrm{CO}_{2}$ (5 y $100 \%)$. La velocidad de corrosión de los aceros se midió mediante la técnica de resistencia de polarización. Se ha podido determinar que, bajo las distintas condiciones de humedad relativa y ausencia de agresivo, los aceros se mantuvieron correctamente pasivados en los morteros con contenidos de FC3R de hasta el 15\%. El nivel de corrosión que presenta el refuerzo embebidos en morteros con sustitución de un 15\% de cemento por FC3R y relación a/mc 0,3 , al ser sometidos a un proceso de carbonatación acelerada, era muy similar al mostrado por el mortero patrón, sin FC3R.

Palabras clave: corrosión, catalizador, carbonatación, acero, cemento.

\section{SUMMARY}

This paper reports on a study of the corrosion levels in steel bars embedded in mortars made with a blend of Portland cement and (0-20\%) spent fluid catalytic cracking catalyst residue (FC3R), with a variable (0.3-0.7) water/binder $(w / b)$ ratio. The specimens were stored in the following conditions: relative humidity of 40,80 or $100 \%$ and $\mathrm{CO}_{2}$ concentrations of 5 and $100 \%$. The steel corrosion rate was measured with polarization resistance techniques. In the absence of aggressive agents, the steel was found to remain duly passivated in mortars with an FC3R content of up to $15 \%$ under all the conditions of relative humidity tested. The reinforcement corrosion level in mortars with a $w / b$ ratio of 0.3 and $15 \%$ FC3R subjected to accelerated carbonation was similar to the level observed in the unblended Portland cement control mortar.

Keywords: corrosion, catalyst, carbonation, steel, cement.

\footnotetext{
(*) Universidad Politécnica de Valencia (Valencia, España).

(**) Universidad de Alicante (Alicante, España).
} 


\section{INTRODUCCIÓN}

La corrosión de las barras de acero del hormigón armado en ambientes industriales o urbanos debido a la carbonatación es un serio problema que afecta a muchas estructuras de hormigón armado. Esta situación puede verse agravada por la incorporación de puzolanas ya que consumen parte de la reserva alcalina del hormigón. Esta circunstancia puede conducir a un descenso de la resistencia a carbonatación de los recubrimientos de hormigón de las armaduras, y por tanto, a un aumento del riesgo de corrosión de las barras de acero.

En trabajos previos se ha investigado la influencia de la adición de adiciones minerales a la resistencia a corrosión del hormigón armado sometido a carbonatación. Con respecto al uso de escorias de alto horno, Baccay y col. (1) afirmaban que el hormigón con cemento Portland tenía una mejor resistencia a corrosión que el cemento con escorias de alto horno ante un ataque por carbonatación. Por otro lado, Pal y col. (2) obtuvieron resultados opuestos, afirmando que un aumento en la proporción de escoria producía un descenso de la velocidad de corrosión de las armaduras ante los procesos de carbonatación. Sin embargo, Parrot (3) presentó resultados según los cuales la profundidad de carbonatación registrada en el hormigón era mayor cuando se sustituía parte del cemento Portland por un $19 \%$ o más de escoria de alto horno. En la misma línea, Parrot (4) mostró que la corrosión era superior cuando se incorporaba un $50 \%$ de escoria de alto horno en el cemento. En el caso del metacaolín, un estudio realizado por Batis y col. (5) afirmaba que el uso de metacaolín, ya fuera como sustitución de hasta el $20 \%$ de arena o como sustitución de hasta el $10 \%$ de cemento, mejoraba el comportamiento a la corrosión de los aceros embebidos en probetas de mortero, mientras que cuando el metacaolín se adicionaba en cantidades superiores no se observaban efectos positivos. El efecto de la adición de ceniza volante ha mostrado que puede producir tanto efectos positivos (6) como negativos $(4,7)$ en la corrosión de los aceros.

Recientemente, varios investigadores han enfocado sus trabajos en el residuo de catalizador de craqueo catalítico (FC3R) para usarlo como sustitución de parte del cemento en morteros y hormigones debido a su alta actividad puzolánica (8-14). El FC3R está compuesto principalmente por silicoaluminatos presentando una mineralogía similar a la faujasita. El FC3R ha mostrado una elevada mejora de las propiedades mecánicas debido a la formación de productos cementantes adicionales y la mejora del empaquetamiento en la interfase entre árido y la pasta de cemento (15-18). En relación con la durabilidad de los aceros embebidos en morteros que incorporan FC3R, Pacewska y col. estudiaron la influencia del residuo de catalizador en la hidratación del cemento y en el esta-

\section{INTRODUCTION}

Carbonation-induced steel bar corrosion is a serious problem that affects many reinforced concrete structures in industrial and urban environments. This situation may be aggravated when the cement is blended with pozzolans, which lower the alkaline reserve and with it the carbonation resistance of the concrete cover, thereby raising the risk of steel bar corrosion.

The effect of mineral additions on the corrosion resistance of reinforced concrete subjected to carbonation has been studied by a number of authors. Baccay et al. (1) reported that Portland cement concrete exhibited higher carbonation corrosion resistance than concrete containing blast furnace slag. Pal et al. (2), in turn, observed the opposite, claiming that higher proportions of slag lowered the carbonation-induced corrosion rate in the reinforcement. According to Parrot's findings (3), however, the carbonation depth was greater in concrete when $19 \%$ or more of the Portland cement was replaced with blast furnace slag. In this same vein, Parrot (4) showed that corrosion was greater when $50 \%$ of the binder consisted in blast furnace slag. Batis et al. (5) reported that metakaolin, whether used to replace $20 \%$ of the sand or $10 \%$ of the cement, improved the corrosion performance of steel embedded in mortar specimens, although no beneficial effects were observed when higher percentages of this substance were used. The addition of fly ash has proved to affect steel corrosion both beneficially (6) and adversely $(4,7)$.

Several authors have recently studied fluid catalytic cracking catalyst residue (FC3R) as a replacement for part of the cement in mortars and concretes, in light of its high pozzolanic activity (8-14). FC3R, which consists primarily of silicoaluminates, has a mineralogy reminiscent of faujasite. The catalyst has been shown to improve the mechanical properties of mortars and concretes by inducing the formation of additional cementitious products and better particle packing at the aggregate - cement paste interface (15-18). Studying the effect of FC3R on cement hydration and the passivation of embedded steel, Pacewska et al. found a relationship between its fineness and its behaviour in mortars (as a microfiller or active pozzolan). They also concluded that in the absence of 
do de pasivación de aceros embebidos mostrando que existe una relación entre su finura y comportamiento que ofrece en los morteros (como microfiller o como puzolana activa), y también concluyeron que no se producía deterioro en las condiciones de pasivación de los aceros durante la etapa de curado y en ausencia de agentes agresivo como los cloruros o la carbonatación $(19,20)$.

Así pues, el FC3R puede ser útil para mejorar las propiedades mecánicas del hormigón pero también reduce la reserva alcalina del hormigón lo que puede ofrecer un riesgo adicional para las armaduras, ya que la reserva alcalina es el principal factor que garantiza las condiciones químicas protectoras alrededor de las barras de acero. Hasta el momento, en la bibliografía no existe ningún trabajo en el que se haya estudiado la influencia del FC3R en el comportamiento frente a la corrosión de los aceros embebidos en morteros ante un proceso como la carbonatación del recubrimiento.

El objetivo de este trabajo es evaluar cómo la sustitución parcial de cemento por FC3R afecta al nivel de corrosión de las armaduras del hormigón ante un ataque por carbonatación y bajo diversas condiciones ambientales de humedad relativa. También se evalúa la influencia que pueden tener los parámetros de relación agua/material cementante $(\mathrm{a} / \mathrm{mc})$ y nivel de sustitución de cemento por FC3R en las velocidades de corrosión de las armaduras.

\section{DESCRIPCIÓN EXPERIMENTAL}

Materiales y preparación de probetas. El cemento utilizado en la preparación de los morteros fue cemento Portland tipo CEM I $52.5 \mathrm{R}$, de producción local. El árido utilizado en todos los casos fue arena silícea normalizada y agua destilada. Se prepararon diferentes tipos de mortero variando la relación a/mc: 0,3 y 0,4 con plastificante (Sika Viscocrete), y 0,5 y 0,7 sin plastificante. Se realizaron varias sustituciones parciales de cemento por FC3R (suministrado por BP Oil España) en los siguientes porcentajes para cada una de las relaciones a/mc: $0 \%$, $5 \%, 10 \%, 15 \%$ y $20 \%$. La relación árido/material cementante fue de 3/1 en todos los casos. Las probetas fabricadas fueron prismas de dimensiones $20 \times 60 \times 80 \mathrm{~mm}$ (Figura 1). Se embebieron dos electrodos de acero de 8 $\mathrm{mm}$ de diámetro y un contraelectrodo adicional de grafito en las probetas durante la fabricación de las mismas. Todos los valores de velocidad de corrosión (Icorr) y potencial de corrosión (Ecorr) presentados en este estudio corresponden al valor medio de los dos electrodos de acero de cada probeta.

Almacenamiento de las probetas. Durante todo el desarrollo del estudio se midió la Icorr y el Ecorr de los aceros. Las probetas permanecieron en cada uno de los aggressive agents such as chlorides or carbonation, steel passivation was unaffected during the curing stage $(19,20)$.

While FC3R may, then, be useful for enhancing concrete mechanical strength, it also lowers the alkaline reserve in concrete. This may raise reinforcement corrosion risk, for the alkaline reserve is the main guarantee of chemical protection for steel bars. To date, nothing has been published in the literature on the corrosion performance of steel embedded in mortars containing FC3R when exposed to carbonation.

The present study aimed to evaluate how the partial replacement of cement by FC3R affects carbonationinduced corrosion in concrete reinforcement under different relative humidity conditions. The possible effect of the water/binder $(w / b)$ ratio and the percentage of FC3R in the cement on reinforcement corrosion rates was likewise evaluated.

\section{EXPERIMENTAL}

Materials and specimen preparation. The mortars were prepared with locally produced CEM I $52.5 R$ Portland cement. The other components were standardized siliceous sand as the aggregate and distilled water. Mortars were prepared with four $w / b$ ratios ( 0.3 and 0.4 with a plasticizer (Sika Viscocrete), and 0.5 and 0.7 with no plasticizer) and five cement blends, each with a different percentage of FC3R (supplied by BP Oil España): $0 \%, 5 \%, 10 \%, 15 \%$ and $20 \%$. The aggregate/binder ratio was $3 / 1$ in all the mortars. The prismatic specimens

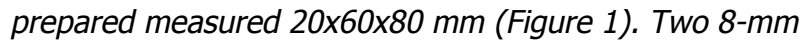
diameter steel electrodes as well as a graphite counterelectrode were embedded in each specimen. All the corrosion rate (Icorr) and corrosion potential (Ecorr) values given in this paper are the means of the readings for the two steel electrodes in each specimen.

Specimen storage. Steel Icorr and Ecorr values were measured throughout the study period. The specimens were stored in each of the environments shown on the 


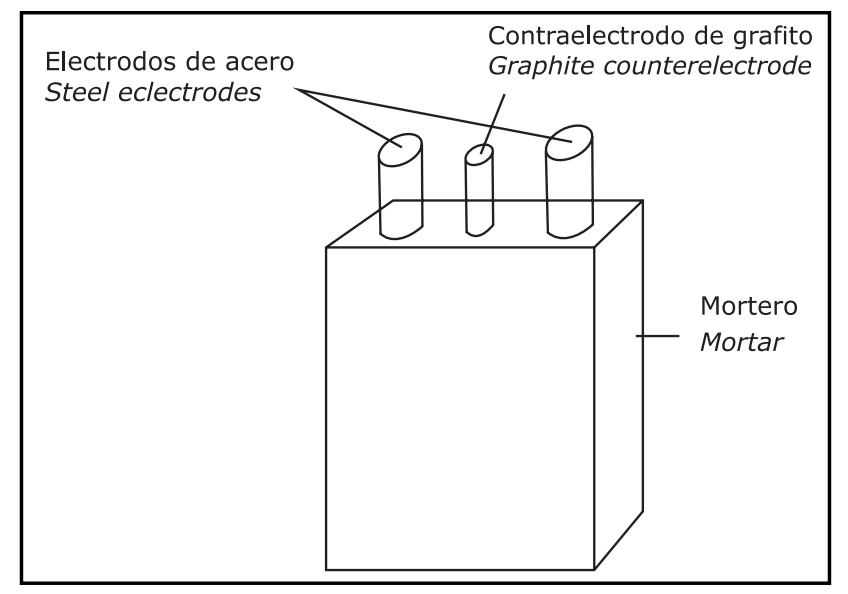

Figura 1. Probeta utilizada en las medidas de corrosión.

Figure 1. Specimen used to measure corrosion.

ambientes que se detallan en la Figura 2 hasta que alcanzaron niveles estacionarios en Icorr y Ecorr. Durante la etapa de carbonatación acelerada la humedad relativa en la cámara de carbonatación se mantuvo en el $65 \pm 5 \%$ para que el proceso de carbonatación acelerada fuera más rápido. Para comprobar el avance del proceso de carbonatación de la capa de recubrimiento se utilizaron testigos prismáticos $(20 \times 20 \times 80 \mathrm{~mm})$ del mismo material que el recubrimiento que se almacenaron en las mismas condiciones que las probetas de corrosión. Estos testigos se fracturaron periódicamente y su sección se reveló mediante fenolftaleína. Por último, las probetas se volvieron a mantener en una cámara húmeda con una humedad relativa del $100 \%$ para comprobar los niveles de corrosión a los que darían lugar los aceros tras la exposición a las atmósferas de elevada concentración de $\mathrm{CO}_{2}$, cuya etapa produce un descenso de la cantidad de electrolito presente en los poros y puede limitar el desarrollo de la corrosión por control óhmico.

Medidas de velocidad de corrosión. Con el objetivo de registrar el estado de los aceros durante el ensayo se midieron dos parámetros: Icorr y Ecorr. Los valores de Ecorr se midieron frente a un electrodo de referencia de calomelanos saturado (SCE). Para registrar la evolución flowchart in Figure 2 until the Icorr and Ecorr values stabilized. During accelerated carbonation, the relative humidity in the carbonation chamber was kept at $65 \pm 5 \%$ to expedite the process. The advance of the carbonation front in the concrete cover was monitored with prismatic samples $(20 \times 20 \times 80 \mathrm{~mm})$ made with the same mortar as the cover in the corrosion specimens and stored under the same conditions. These samples were periodically split open and their sections coated with the acid-base indicator phenolphthalein. Lastly, the specimens were kept in a chamber at a relative humidity of $100 \%$ to determine the corrosion levels that would be found in the steel after exposure to atmospheres with high $\mathrm{CO}_{2}$ concentrations, conditions that may reduce the amount of electrolyte present in the pores and thereby limit corrosion via ohmic control.

Corrosion rate measurements. The two parameters measured to record the condition of the steel during the test were Icorr and Ecorr. The Ecorr values were measured against a saturated calomel electrode (SCE). Steel Icorr was monitored with the polarization resistance technique

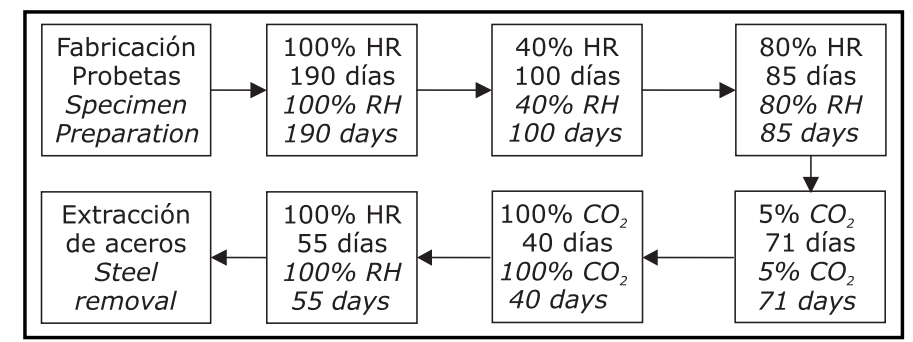

Figura 2. Esquema de las condiciones ambientales a las que se han sometido las probetas.

Figure 2. Environmental conditions to which the specimens were subjected. 
de la Icorr de los aceros se usó la técnica de resistencia de polarización $(21,22)$ para lo cual se utilizó un potenciostato Princeton Applied Research EG\&G modelo 362. El barrido de polarización se realizó desde el valor de (Ecorr-10 mV) hasta (Ecorr+10mV) con una velocidad de barrido de $0.5 \mathrm{mV} / \mathrm{s}$. Una vez que todas las condiciones experimentales fueron ensayadas, al final del programa experimental, los electrodos de acero se limpiaron y se pesaron para contrastar las medidas realizadas mediante la técnica de resistencia de polarización (a través de la ley de Faraday) con la pérdida de masa gravimétrica de los electrodos (cambio de masa durante todo el proceso de ensayo).

Porosimetría de intrusión de mercurio. Se tomaron muestras de algunos de morteros preparados y se analizaron mediante un equipo Autopore IV 9500 V1.05 de la empresa Micromeritics Instrument Corporation. Se analizaron tres replicados de cada mortero de un volumen aproximado de $1 \mathrm{~cm}^{3}$. Los análisis se realizaron en el intervalo de presiones desde 0,5 a 33000 psia.

\section{RESULTADOS Y DISCUSIÓN}

\subsection{Influencia de la relación $\mathrm{a} / \mathrm{mc}$, del porcentaje de FC3R y de la humedad relativa}

En todas las gráficas de Icorr que se presentan, la zona señalada comprendida entre 0,1 y $0,2 \mu \mathrm{A} / \mathrm{cm}^{2}$, corresponde al límite de corrosión activa, definido este como la velocidad de corrosión a partir de la cual se ha producido la ruptura, ya sea local o generalizada, de la capa de pasivación de la superficie de los aceros $(23,24)$.

En la Figura 3 se presenta la evolución de Icorr y Ecorr de los aceros embebidos en los morteros con distintas relaciones $\mathrm{a} / \mathrm{mc}$ para dos niveles de sustitución de cemento por FC3R ( $0 \%$ y $15 \%)$, almacenados en cámara húmeda en un ambiente del $100 \%$ de humedad relativa. Los valores de Icorr de los aceros embebidos en los morteros sin FC3R (Figura 3 izda.) se situaron por debajo de $0,066 \mu \mathrm{A} / \mathrm{cm}^{2}$ en el ambiente de $100 \% \mathrm{HR}$ para todas las relaciones $\mathrm{a} / \mathrm{mc}$. Los potenciales de corrosión promedio registrados para los aceros en estas condiciones se mantuvieron en el intervalo entre -114 y $-329 \mathrm{mV}$. En estas mismas condiciones, los valores de Icorr de los aceros embebidos en los morteros con un 15\% de FC3R (Figura 3 dcha.), fueron inferiores a 0,102 $\mu \mathrm{A} / \mathrm{cm}^{2}$. Los potenciales de corrosión promedio de estos aceros estuvieron comprendidos entre -121 y $-324 \mathrm{mV}$. Por lo tanto, se pudo comprobar que no se superaban los niveles de corrosión activa en ningún caso para los aceros con cualquiera de las relaciones $\mathrm{a} / \mathrm{mc}$ empleadas. No obstante, como se observa en la Figura 3, los valores de Icorr de
$(21,22)$, using a Princeton Applied Research EG\&G model 362 potentiostat. The polarization scanning range was Ecorr-10mV to Ecorr $+10 \mathrm{mV}$ and the scanning rate 0.5 $\mathrm{mV} / \mathrm{s}$. After finalization of the experimental programme, the steel electrodes were cleaned and weighed to compare the polarization resistance technique measurements (applying Faraday's law) to electrode gravimetric loss (change in mass during the test).

Mercury intrusion porosimetry. Samples of some of the mortars prepared were analyzed with a Micromeritics Instrument Corporation Autopore IV 9500 V1.05 porosimeter. Three $1-\mathrm{cm}^{3}$ replicates of each mortar were analyzed at a pressure range of 0.5 to 33000 psia.

\section{RESULTS AND DISCUSSION}

\subsection{Effect of the $w / b$ ratio, percentage of FC3R and relative humidity}

In all the Icorr graphs shown, the shaded area between 0.1 and $0.2 \mu \mathrm{A} / \mathrm{cm}^{2}$ marks the threshold for active corrosion, defined to be the corrosion rate at which the passivation layer on the steel surface is completely or locally damaged $(23,24)$.

Figure 3 shows the variation in steel Icorr and Ecorr values in mortars with different $w / b$ ratios and 0 and $15 \%$ FC3R, stored in a humidity chamber at $100 \%$ relative humidity. The Icorr values for the steel embedded in FC3R-free mortars (Figure 3, left) were under 0.066 $\mu A / \mathrm{cm}^{2}$ for all the $\mathrm{w} / \mathrm{b}$ ratios. The mean corrosion potential values recorded for the steel under these conditions ranged from -114 to $-329 \mathrm{mV}$. The Icorr values for the steel embedded in mortars with 15\% FC3R (Figure FC3R, right) were lower than $0.102 \mu \mathrm{A} / \mathrm{cm}^{2}$. The mean corrosion potentials for these steel bars ranged from -121 to -324 mV. In other words, the active corrosion threshold was not reached in any of the steel electrodes at any of the $w / b$ ratios used. Nonetheless, as Figure 3 shows, the Icorr values for the steel in mortars with $15 \%$ FC3R were higher than obtained for the steel in mortars with 0\% FC3R. Furthermore, while the Ecorr values varied widely depending on the $w / b$ ratio, this was not reflected in the 
los aceros de los morteros con un $15 \%$ de FC3R son superiores a los obtenidos por los aceros de los morteros sin FC3R. Asimismo, se observó que a pesar de presentar valores de Ecorr muy diferentes entre las distintas relaciones a/mc, no se observó su reflejo en los valores de Icorr debido a que los aceros permanecían en estado pasivo.
Icorr values, for the steel remained passivated throughout.

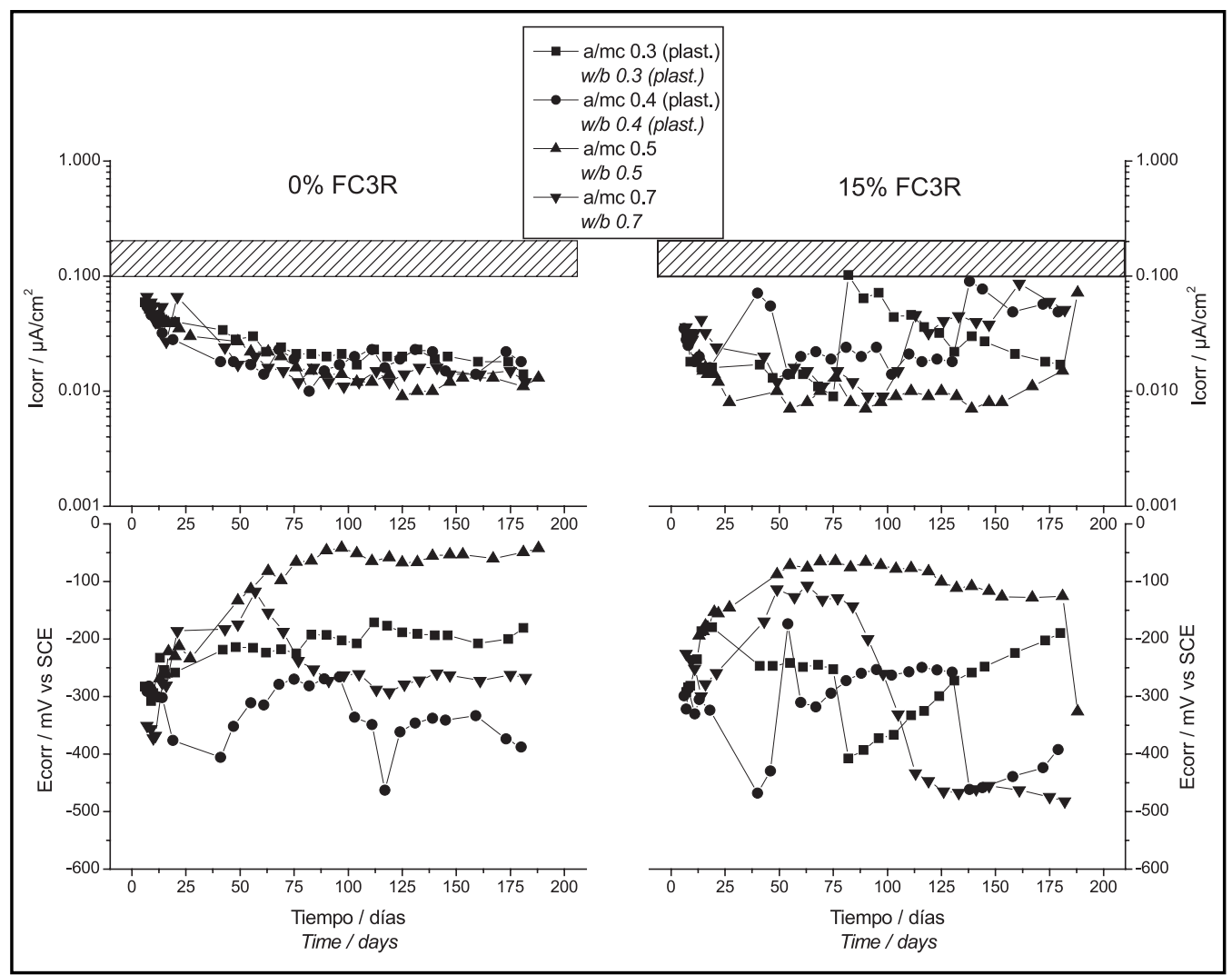

Figura 3. Icorr y Ecorr de aceros embebidos en morteros con $0 \%$ y $15 \%$ de FC3R a $100 \%$ de humedad relativa. Figure 3. Icorr and Ecorr values for steel embedded in mortar with $0 \%$ and 15\% FC3R at $100 \%$ relative humidity.

La Figura 4 muestra la evolución de Icorr y Ecorr de los aceros embebidos en morteros con distintos porcentajes de sustitución de cemento por FC3R, con una relación a/mc constante de 0,5 y almacenados en cámara húmeda a una HR del $100 \%$. Los valores de Icorr de los aceros embebidos en los morteros se situaron sistemáticamente por debajo de $0,072 \mu \mathrm{A} / \mathrm{cm}^{2}$ para sustituciones de hasta el $15 \%$ de cemento por FC3R. Los aceros embebidos en el mortero con un $20 \%$ presentaron Icorr superiores a los anteriores, llegando a alcanzar los 0,196 $\mu \mathrm{A} / \mathrm{cm}^{2}$ Los potenciales de corrosión promedio de estos aceros embebidos en los morteros con una sustitución de FC3R de hasta el $15 \%$ oscilaron entre -113 y $-212 \mathrm{mV}$, mientras que los aceros correspondientes al mortero con un $20 \%$ presentaron un valor promedio más negativo, en torno a -376 mV. Así pues, se pudo comprobar que los aceros embebidos en los morteros con porcentajes de FC3R de hasta el $15 \%$ presentaban valores de Icorr y Ecorr indi-
Figure 4 shows the variations in the Icorr and Ecorr values of steel embedded in mortar with different FC3R contents and a constant $w / b$ ratio of 0.5 , after storage in a humidity chamber at $100 \% \mathrm{RH}$. The Icorr values for the steel embedded in these mortars were consistently lower than $0.072 \mu \mathrm{A} / \mathrm{cm}^{2}$ for FC3R contents of up to $15 \%$. The steel embedded in the mortar with 20\% FC3R exhibited Icorr values of up to $0.196 \mu \mathrm{A} / \mathrm{cm}^{2}$, higher than in the preceding cases. The mean corrosion potential of the steel embedded in mortars with up to 15\% FC3R ranged from -113 to $-212 \mathrm{mV}$, whereas the value observed for the steel in the mortar with $20 \%$ of the cement substitute was more negative, at around $-376 \mathrm{mV}$. These findings confirmed that steel embedded in mortars with FC3R percentages of up to $15 \%$ had Icorr and Ecorr values indicative of passivation, whereas the clear decline in corrosion resistance when the content was $20 \%$ was a possible sign of inadequate passivation. This finding may be 
cativos del estado de pasivación, mientras que la sustitución del $20 \%$ ofreció claramente un peor comportamiento frente a la corrosión, pudiendo indicar que la pasivación de estos aceros no era adecuada. Este hecho podría explicarse debido a un probable aumento en la porosidad de este mortero, ya que se observó que la trabajabilidad del mismo era menor que para el resto de morteros debido a la elevada demanda de agua del FC3R. explained by a probable increase in porosity: in fact, this mortar was observed to be less workable than the others due to the high water demand exhibited by FC3R.

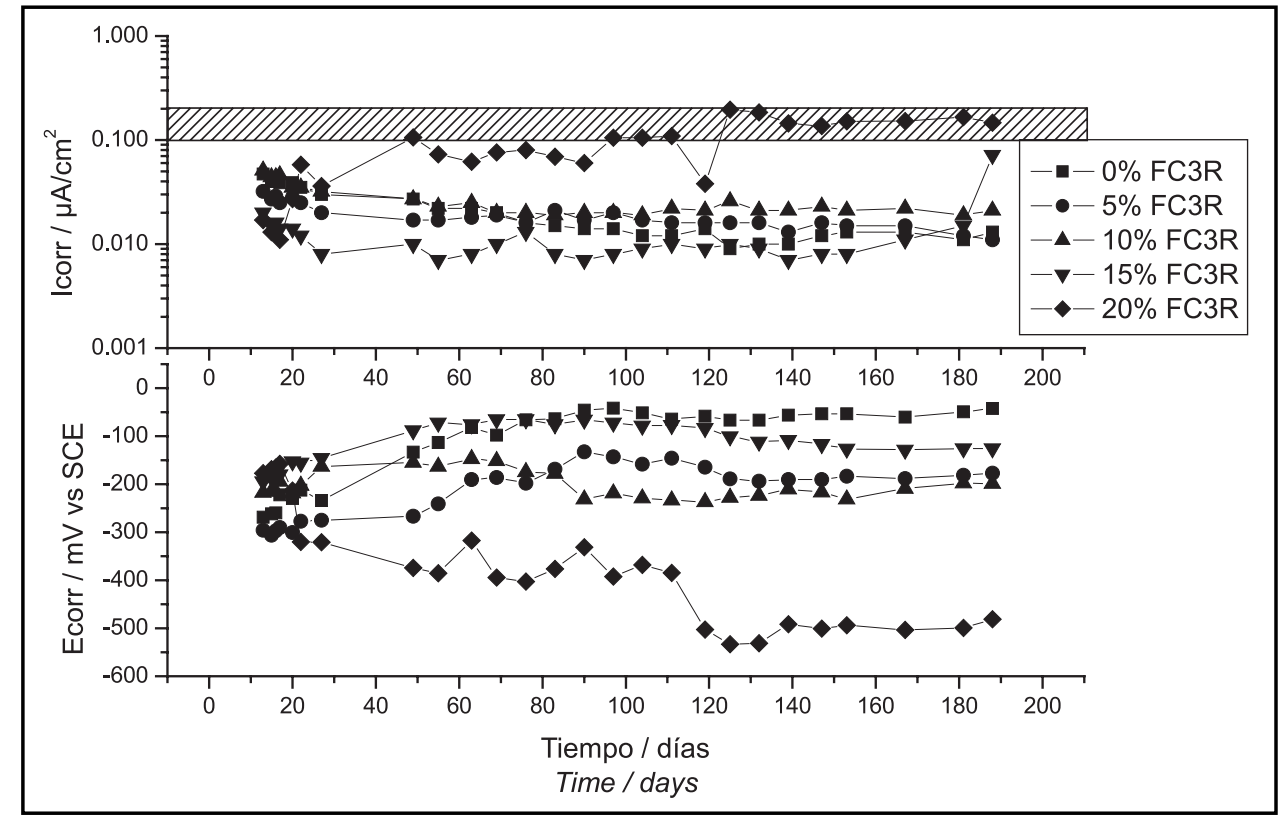

Figura 4. Icorr y Ecorr de aceros embebidos en morteros con distintas sustituciones de FC3R y relación a/mc de 0,5 a $100 \%$ de humedad relativa.

Figure 4. Icorr and Ecorr values for steel embedded in mortar with different percentages of FC3R, a $w / b$ ratio of 0.5 and $100 \%$ relative humidity.

Comparando el comportamiento exhibido por el FC3R con el de otras puzolanas en ambientes parecidos se pudieron observar influencias en las velocidades de corrosión y potenciales de corrosión similares. En general, la sustitución de cemento por humo de sílice (en cantidades de hasta el $15 \%$ ) producía poca influencia en los valores de Icorr en ausencia de agentes agresivos como los cloruros o el dióxido de carbono y en condiciones de elevada humedad relativa (25-27). Por su parte, algunos autores apuntaron que el uso de escorias de alto horno (en cantidades en torno al $50 \%$ ) ofrecía claras mejoras en los niveles de corrosión produciendo mayores potenciales de corrosión, menores velocidades de corrosión y un retraso en los tiempos de iniciación cuando las probetas se sometían a un ataque por cloruros $(2,25,28-30)$. En un ataque por carbonatación, a pesar de que la carbonatación de los recubrimientos de los morteros con escoria era superior, los valores de Icorr que se alcanzaban en los aceros no eran significativamente mayores $(1,4,28)$. Con respecto al comportamiento ofrecido por las cenizas
A comparison of FC3R behaviour to the performance of other pozzolans in analogous environments revealed that the effects on corrosion rates and potential were similar. As a rule, cement replacement by silica fume (up to 15\%) had a scant impact on Icorr values in the absence of aggressive agents such as chlorides or carbon dioxide under conditions of high relative humidity (25-27). Several authors have reported that the use of (up to $50 \%$ ) blast furnace slag led to visible improvements in corrosion levels, with higher corrosion potentials, lower corrosion rates and retarded starting times when the specimens were exposed to chloride attack $(2,25,28-30)$. In a carbonation attack, even though carbonation was greater in the slag-containing mortar cover, the Icorr values reached in the steel were not significantly higher $(1,4$, 28). At replacement percentages of from 10 to $20 \%$, fly ash, in turn, prompted no increase in corrosion rates in the absence of aggressive agents or exposure to carbonation $(25,28,29)$. The use of higher proportions of ash, however, led to a decline in corrosion performance $(4,7)$. 
volantes, éstas no producen aumentos en las velocidades de corrosión en ausencia de agresivo o ante los procesos de carbonatación $(25,28,29)$ cuando se utilizan en cantidades comprendidas entre el 10 y el $20 \%$. El uso de mayores proporciones de ceniza hacía que se empeoraran los niveles de corrosión $(4,7)$. En resumen, se ha podido observar que el empleo de puzolanas (incluido el FC3R) en cantidades comprendidas entre el 10 y el $20 \%$ ofrece niveles de corrosión similares a los que tendrían los aceros embebidos en mortero de cemento Portland en ausencia de procesos como la carbonatación o el ingreso de cloruros.

La Figura 5 muestra la evolución de Icorr y Ecorr de los aceros embebidos en morteros con y sin sustitución de cemento por FC3R, con una relación $\mathrm{a} / \mathrm{mc}$ fija de 0,5 y almacenados en ambientes con valores distintos de humedad relativa: $100 \%, 80 \%$ y $40 \%$. Los valores de Icorr de los aceros embebidos en los morteros sin FC3R y con un $15 \%$ de FC3R se situaron en torno a los 0,016 $\mu \mathrm{A} / \mathrm{cm}^{2}$ aproximadamente, y no se pudieron apreciar grandes diferencias entre los valores registrados en las distintas humedades relativas. En los potenciales de
Summarizing, in the absence of carbonation or chloride penetration, the corrosion levels in mortars containing from 10 to $20 \%$ pozzolans (FC3R included) were similar to the levels observed for steel embedded in unblended Portland cement.

Figure 5 shows the variations in the Icorr and Ecorr values of steel embedded in mortar with and without $F C 3 R$ and a constant $w / b$ ratio of 0.5 after storage in environments with relative humidity values of $100 \%$, $80 \%$ and $40 \%$. The Icorr values of steel embedded in mortar with 0 and 15\% FC3R hovered around approximately $0.016 \mu \mathrm{A} / \mathrm{cm}^{2}$, with no major differences between the values recorded for the various $\mathrm{RH}$ levels. While relative humidity did affect corrosion potential somewhat, no difference was observed in the behaviour of the steel in

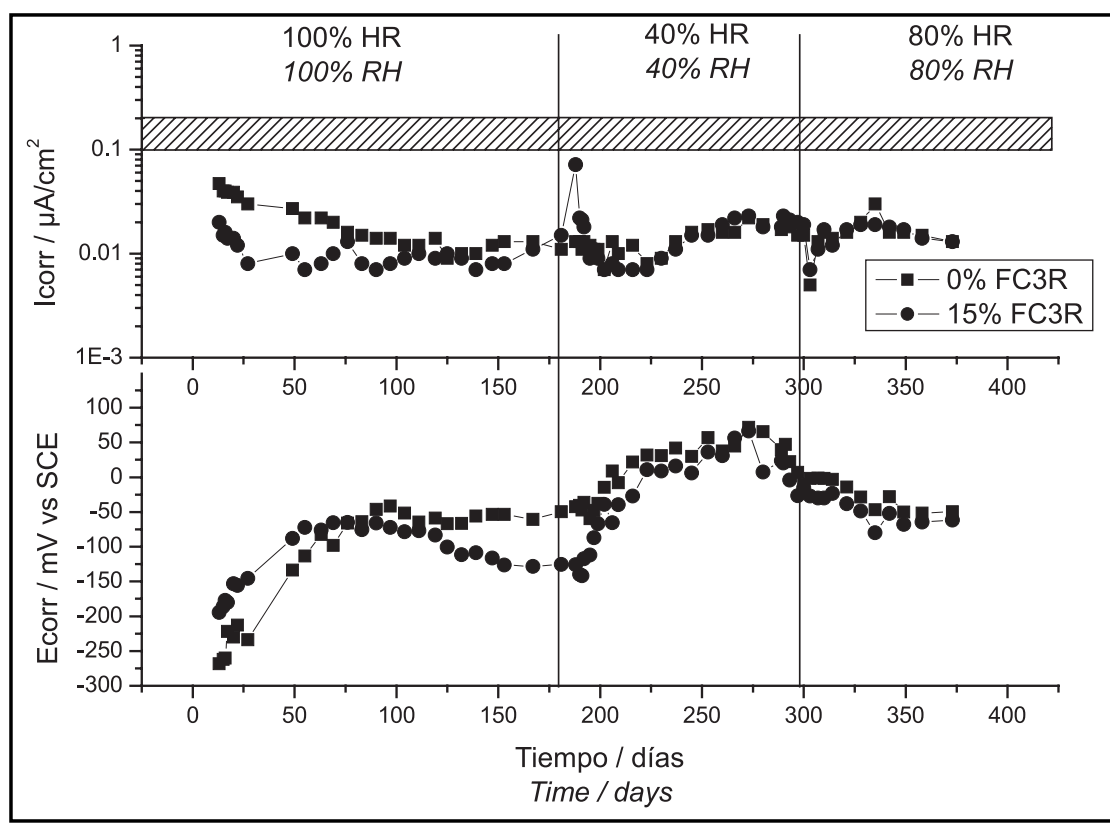

Figura 5. Icorr y Ecorr de aceros embebidos en morteros con una relación a/mc de 0.5 para distintas condiciones de humedad relativa.

Figure 5. Icorr and Ecorr values for steel embedded in mortar with a w/b ratio of 0.5 and variable relative humidity.

corrosión sí que se pudo apreciar cierta influencia de la $\mathrm{HR}$, aunque nuevamente no existía diferencia de comportamiento entre los aceros del mortero sin FC3R y los correspondientes al mortero con un $15 \%$ de FC3R. En concreto, en la parte final de cada una de las HR en las mortars with $0 \%$ and $15 \%$ FC3R. Specifically, at the end of the trials, the Ecorr values measured were around -100 $\mathrm{mV}$ for $100 \% \mathrm{RH},+50 \mathrm{mV}$ for $40 \% \mathrm{RH}$ and $-50 \mathrm{mV}$ for $80 \% \mathrm{RH}$. The decline in Ecorr with increasing $\mathrm{RH}$ was due to the reduction in the partial pressure of $\mathrm{O}_{2}$ on the sur- 
que se mantuvieron las probetas se midieron valores de Ecorr en torno a $-100 \mathrm{mV}$ para la $\mathrm{HR}$ del $100 \%,+50 \mathrm{mV}$ para la HR del $40 \%$ y $-50 \mathrm{mV}$ para la HR del $80 \%$. Por lo tanto, se pudo observar que según aumenta la HR del medio se producía un descenso en el Ecorr debido a que la presión parcial de $\mathrm{O}_{2}$ en la superficie de los electrodos de acero se reducía. No obstante, pese a los cambios observados en Ecorr, no se apreció que se modificara la Icorr de los aceros, ya que éstos todavía conservaban su estado de pasivación, tal y como se deduce de los bajos valores de Icorr que se midieron. Esto se debe a que los desplazamientos del potencial hacia valores más negativos que pueden tener lugar debido al descenso de la concentración de oxígeno (lo cual puede producir cambios en la composición de la fase acuosa) no incrementan necesariamente la velocidad de corrosión al no implicar un cambio suficiente en la morfología y compacidad de la capa pasivante (31).

\subsection{Influencia del proceso de carbonatación ace- lerada}

La Figura 6 muestra la evolución de los valores de Icorr y Ecorr de los aceros embebidos en morteros con y sin sustitución de cemento por FC3R, para distintas relaciones $\mathrm{a} / \mathrm{mc}$, cuando fueron sometidos a un proceso de carbonatación acelerada en dos atmósferas agresivas distintas: $5 \%$ y $100 \%$ de $\mathrm{CO}_{2}$, al $65 \pm 5 \%$ de humedad relativa.

En una primera etapa la atmósfera fue del $5 \%$ de $\mathrm{CO}_{2}$ y los valores de Icorr de los aceros embebidos en los morteros se situaron por debajo de la zona de corrosión acti- face of the steel electrodes. Nonetheless, despite the changes observed in Ecorr, no variation was found in steel Icorr, whose low values indicated effective passivation of the reinforcement. This is because the shift in potential to more negative values due to the decline in oxygen concentration (which may prompt changes in the composition of the aqueous phase) does not necessarily raise the corrosion rate, for passivating layer morphology and compactness remain intact (31).

\subsection{Effect of accelerated carbonation}

Figure 6 shows the variations in the Icorr and Ecorr values of steel embedded in cement mortars with and without FC3R, at different $w / b$ ratios, after exposure to accelerated carbonation in two aggressive atmospheres: $5 \%$ and $100 \% \mathrm{CO}_{2}$, at a relative humidity of $65 \pm 5 \%$.

In the first stage, when the atmosphere contained 5\% $\mathrm{CO}_{2}$, the Icorr values of the steel embedded in the mortars were under $0.056 \mu \mathrm{A} / \mathrm{cm}^{2}$, i.e., below the active

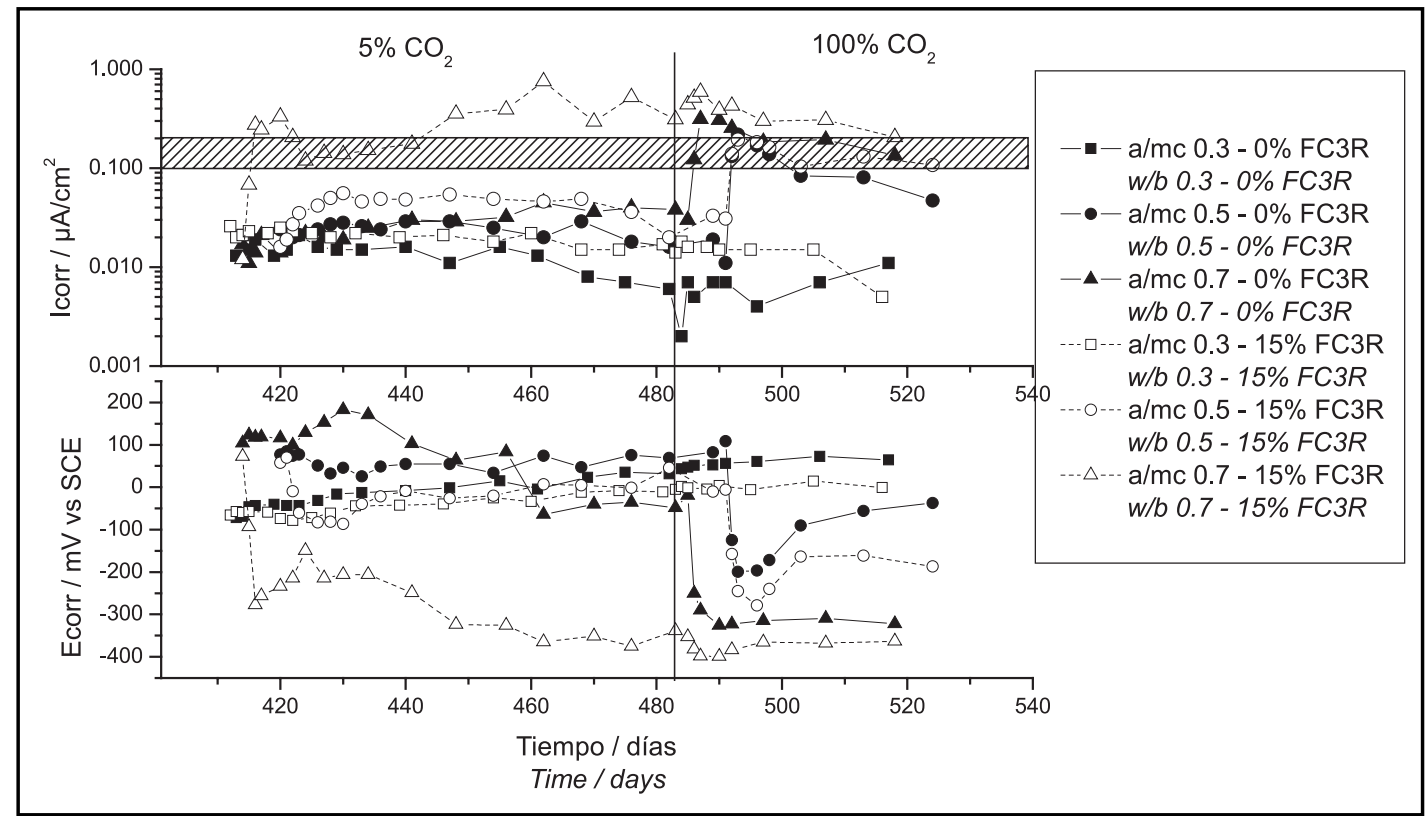

Figura 6. Icorr y Ecorr de aceros embebidos en morteros con $0 \%$ y $15 \%$ de FC3R durante el proceso de carbonatación acelerada. Figure 6. Icorr and Ecorr values for steel embedded in mortar with $0 \%$ and 15\% FC3R during accelerated carbonation. 
va presentando valores por debajo de 0,056 $\mu \mathrm{A} / \mathrm{cm}^{2}$, excepto para los aceros correspondiente al mortero con relación a/mc de 0,7 y un $15 \%$ de FC3R. Dicha probeta presentó a los pocos días de iniciar el ataque con $\mathrm{CO}_{2}$, un aumento de Icorr que se estabilizó en valores en torno a $0,400 \mu \mathrm{A} / \mathrm{cm}^{2}$, situándose claramente en la zona de corrosión activa. Los valores de Ecorr que se obtuvieron durante esta primera etapa de ataque con $\mathrm{CO}_{2}$ estuvieron comprendidos entre +180 y $-90 \mathrm{mV}$, lo que se correspondía con estados de corrosión inactivos, excepto los aceros que habían manifestado un aumento en Icorr $(\mathrm{a} / \mathrm{mc}$ 0.7, $15 \%$ FC3R) en los que se pudo apreciar un desplazamiento del potencial hacia valores más negativos $(-350 \mathrm{mV})$ que indicaban que se había producido la despasivación de los aceros. En esta fase, únicamente los aceros embebidos en los morteros con una relación $\mathrm{a} / \mathrm{mc}$ de 0.7 y un $15 \%$ de sustitución de cemento por FC3R pasaron a ofrecer valores corrosión activos. Este mortero mostró la menor resistencia a carbonatación debido a su elevada porosidad (determinada por su elevada relación a/mc, ver Figura 7) y su baja reserva alcalina (consumida por reacción puzolánica (32)). Se puede apreciar un descenso progresivo de los valores de Ecorr de los aceros de este mortero junto con el aumento producido en el valor de Icorr.

En una segunda etapa, el ambiente fue más agresivo: $100 \%$ de $\mathrm{CO}_{2}$ con una humedad relativa del $65 \pm 5 \%$. Los aceros embebidos en los morteros con relación a/mc igual a 0,5 y 0,7 se despasivaron tras unos pocos días como consecuencia de la penetración del frente de carbonatación a través del mortero de recubrimiento. Este fenómeno se observó tanto para los morteros sustituidos como para los no sustituidos, pero los valores de Icorr medidos en los aceros embebidos en los morteros con un $15 \%$ de FC3R eran mayores que sus equivalentes embe- corrosion threshold, except the steel in the mortar that had $a w / b$ ratio of 0.7 and $15 \%$ FC3R. The Icorr for this specimen began to climb only a few days after initiation of the $\mathrm{CO}_{2}$ attack, ultimately stabilizing at values of around $0.400 \mu \mathrm{A} / \mathrm{cm}^{2}$, i.e., clearly in the active corrosion zone. The Ecorr values obtained in this first stage of the $\mathrm{CO}_{2}$ attack ranged from +180 to $-90 \mathrm{mV}$, corresponding to inactive corrosion, with the exception noted above ( $w / b$ 0.7; 15\% FC3R), where potential shifted toward more negative values $(-350 \mathrm{mV})$, indicating that the steel had become de-passivated. In this stage, only the steel embedded in mortars with a $w / b$ ratio of 0.7 and $15 \%$ FC3R content showed active corrosion values. The lower carbonation resistance exhibited by this mortar was due to its high porosity (determined by its high $w / b$ ratio, see Figure 7) and scant alkaline reserve (consumed by the pozzolanic reaction (32)). The Ecorr values of the steel in this mortar were observed to decline progressively as their Icorr values grew.

In the second stage, the environment was more aggressive: $100 \% \mathrm{CO}_{2}$ at a relative humidity of $65 \pm 5 \%$. The steel embedded in mortars with a $w / b$ ratio of 0.5 and 0.7 was de-passivated in a few days' time because the carbonation front advanced across the entire cover. This was observed in mortars both with and without replacement, but the Icorr values measured in the steel embedded in the mortars with 15\% FC3R were higher than in the steel in the respective 0\% FC3R mortars. Moreover, the reinforcement in the mortars with a $w / b$ ratio of 0.3

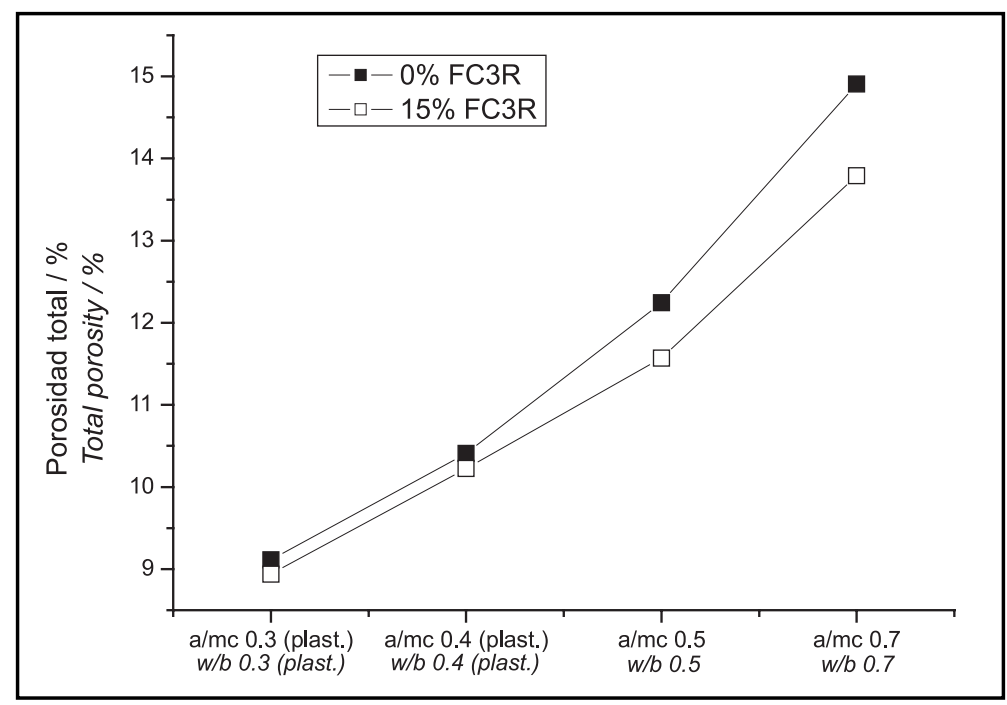

Figura 7. Porosidad total de los morteros de recubrimiento.

Figure 7. Total porosity of mortar cover. 
bidos en los morteros control sin FC3R. Por otro lado, las armaduras de los morteros con una relación a/mc de 0,3 no fueron afectadas por el ambiente corrosivo debido a la baja porosidad de estos morteros, por lo que no se apreciaron cambios en los valores de Icorr y Ecorr en estas condiciones porque los aceros se encontraban muy protegidos del ambiente exterior. Al finalizar esta segunda fase, los niveles de Icorr de los aceros se estabilizaron en valores en torno al umbral de corrosión activa (entre 0,080 y $0,300 \mu \mathrm{A} / \mathrm{cm}^{2}$ ) para los morteros con relación $\mathrm{a} / \mathrm{mc}$ de 0,5 y 0,7 , con y sin sustitución de cemento por FC3R. Por su parte, los aceros de los morteros con relación a/mc baja mantuvieron su Icorr por debajo de 0.010 $\mu \mathrm{A} / \mathrm{cm}^{2}$. Según se observó mediante el revelado con fenolftaleína de los testigos que se colocaron en la cámara de carbonatación, los morteros con relación a/mc de 0,5 y 0,7 (con y sin FC3R) presentaban una carbonatación total, mientras que en los de relación a/mc 0,3 , solamente se había carbonatado hasta una profundidad de 2 $\mathrm{mm}$ desde la superficie del mortero, independientemente de la sustitución de cemento por FC3R.

Tras las etapas de carbonatación, las probetas se almacenaron en una cámara húmeda con una humedad relativa del $100 \%$ para evaluar la velocidad de corrosión real a la que darían lugar los morteros una vez carbonatados. La Figura 8 muestra la evolución de los valores de Icorr y Ecorr de los aceros embebidos en los morteros con y sin sustitución de cemento por FC3R, para diferentes relaciones a/mc. Tras este periodo, los niveles de Icorr de los aceros de los morteros que se carbonataron aumentaron sus niveles de corrosión como consecuencia del aumento were not affected by the corrosive environment due to the low porosity of the mortar. As a result, no change was recorded in the Icorr and Ecorr values under these conditions because the steel was protected from the outside environment. At the end of this second stage, the steel Icorr levels in mortars with $w / b$ ratios of 0.5 and 0.7 , with and without FC3R, stabilized at values around the active corrosion threshold (between 0.080 and 0.300 $\mu A / \mathrm{cm}^{2}$ ). The steel in mortars with a low $w / b$ ratio, in turn, had Icorr values of under $0.010 \mu \mathrm{A} / \mathrm{cm}^{2}$. As observed when the samples stored in the carbonation chamber were coated with phenolphthalein, mortars with $w / b$ ratios of 0.5 and 0.7 (with and without FC3R) were totally carbonated, while the samples made with a $w / b$ ratio of 0.3 were only carbonated to a depth of $2 \mathrm{~mm}$ from the surface of the mortar, whether or not the cement contained FC3R.

After carbonation, the specimens were stored in a humidity chamber at a relative humidity of $100 \%$ to determine the actual corrosion rate in carbonated mortars. Figure 8 shows the variation in Icorr and Ecorr values in steel embedded in mortars with and without FC3R and variable $w / b$ ratios. After storage, the Icorr levels of the steel in the carbonated mortars increased as a result of the higher relative humidity. The steel embedded in mortars with the lowest $w / b$ ratio exhibited Icorr and Ecorr values similar to those recorded in the preceding stages.

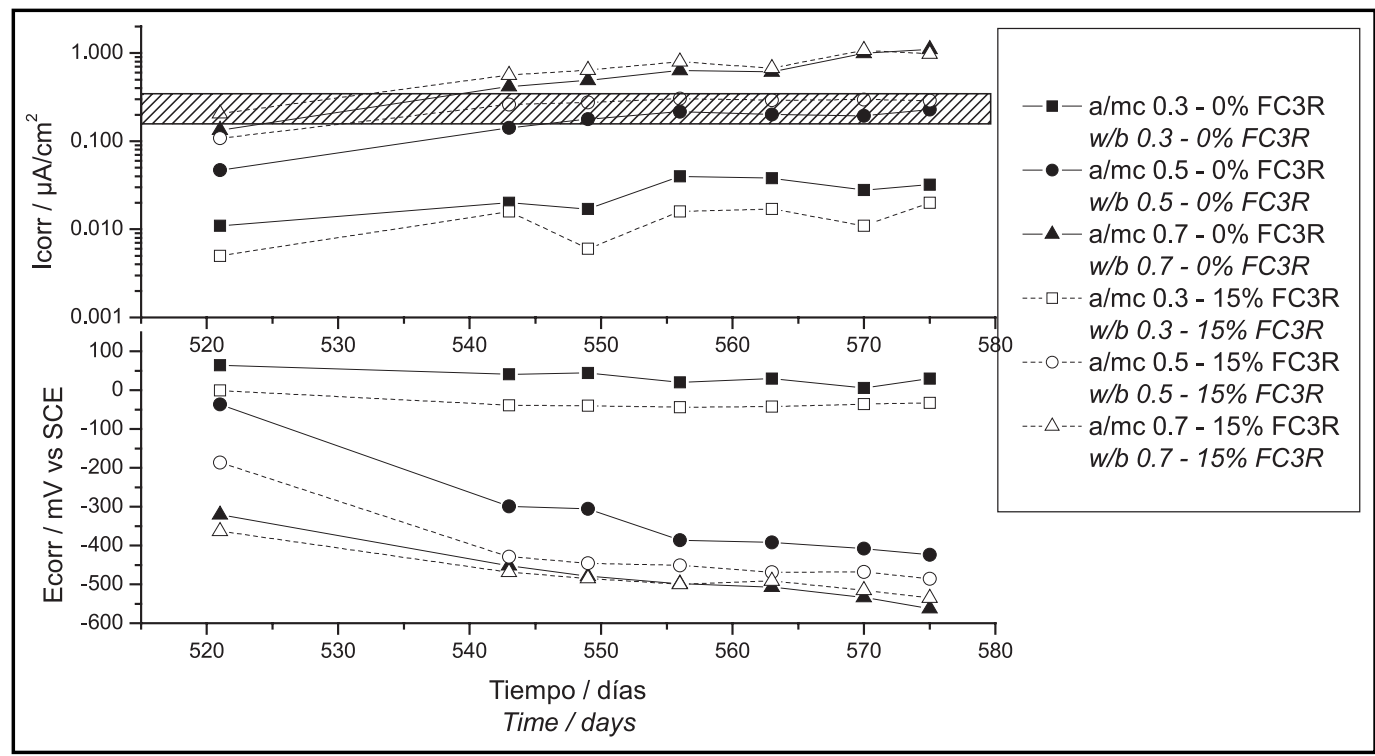

Figura 8. Icorr y Ecorr de aceros embebidos en morteros con $0 \%$ y $15 \%$ tras el proceso de carbonatación acelerada a $100 \%$ de humedad relativa.

Figure 8. Icorr and Ecorr values for steel embedded in mortar with $0 \%$ and 15\% FC3R after accelerated carbonation after storage at $100 \%$ relative humidity. 
en la humedad relativa del ambiente de conservación. Los aceros embebidos en los morteros con la menor relación $\mathrm{a} / \mathrm{mc}$ permanecieron en valores de Icorr y Ecorr muy similares a los que presentaban a lo largo de las etapas anteriores. Esto apoya de nuevo la baja permeabilidad de estos morteros a los agentes químicos externos que pudieran atacar a las armaduras, independientemente de si el FC3R se encontraba presente en el mortero o no. Por el contrario, los aceros embebidos en los morteros con relación a/mc de 0,5 y 0,7 , mostraron un aumento en los valores de Icorr y un descenso en los valores de Ecorr, lo que significa que la corrosión se volvió más activa. Este comportamiento tiene su origen en el aumento de la disponibilidad de electrolito en los poros cuando las probetas se sacaron de la cámara de carbonatación y pasaron a la humedad relativa del $100 \%$, ya que el proceso de carbonatación produce una disminución de la cantidad de electrolito y puede que la corrosión estuviera, en parte, limitada por la baja resistividad del mortero (33-34). Este comportamiento se observó tanto para los morteros sustituidos como para los morteros sin sustituir. Por otro lado, los morteros con la mayor relación $\mathrm{a} / \mathrm{mc}$ presentaron los mayores valores de Icorr y se puede afirmar que estos morteros eran los peores para proteger a las armaduras del ataque por carbonatación.

Una vez que se concluyeron los ensayos de corrosión, al final del programa experimental, las medidas electroquímicas se contrastaron mediante su comparación con las pérdidas de masa gravimétricas de las armaduras. La Figura 9 muestra la comparación de las pérdidas de masa electroquímicas calculadas frente a las pérdidas de masa gravimétricas. Se observó una buena concordancia entre ambos resultados dado que todas las diferencias se encontraban dentro de los límites de error permitidos para la técnica de resistencia de polarización.
This provides further evidence of the low permeability of these mortars to outside chemical agents, regardless of whether FC3R was present in the mortar. By contrast, the Icorr values of the steel embedded in the mortars with $w / b$ ratios of 0.5 and 0.7 rose and their Ecorr values declined, indicating intensified corrosion. The explanation for this behaviour lies in the increase in the availability of the electrolyte in the pores when the specimens were removed from the carbonation chamber and stored at 100\% relative humidity: since carbonation reduces the amount of electrolyte, the low resistivity found in mortar may have partially limited corrosion (33-34). This behaviour was observed in mortars both with and without the catalyst. Moreover, the mortars with the highest $w / b$ ratio had the highest Icorr values, from which it may be inferred that they afforded the reinforcing steel the least effective protection against carbonation.

After the corrosion tests were concluded and the experimental programme finalized, the electrochemical measurements were compared to the actual gravimetric loss in reinforcing steel. Figure 9 compares the loss calculated from the electrochemical findings to the loss of gravimetric mass. The two sets of results were found to concur, with all the differences lying within the acceptable margin of error for polarization resistance techniques.

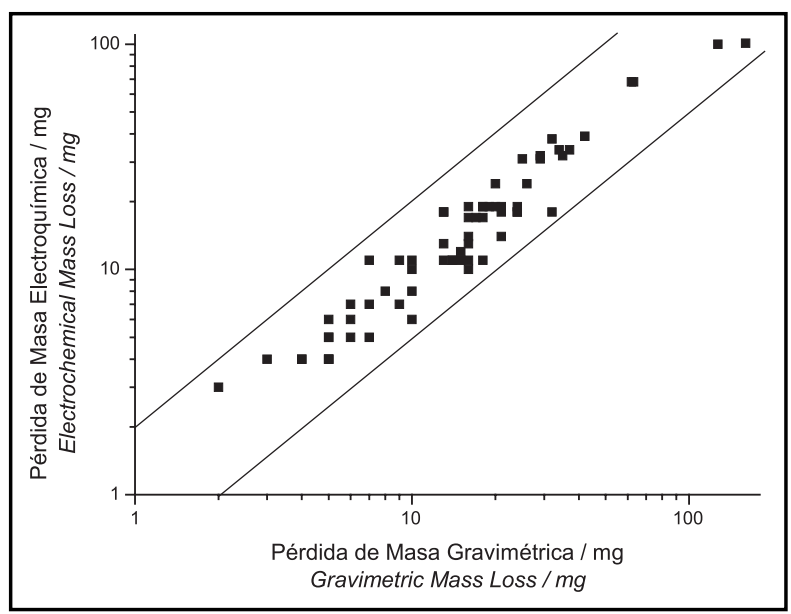

Figura 9. Comparación entre la pérdida de masa electroquímica y la pérdida de masa gravimétrica al final del programa experimental.

Figure 9. Electrochemically calculated mass loss versus loss of gravimetric mass at the end of the experiment. 
La Figura 10 muestra la relación entre los valores de Icorr y Ecorr de todas las medidas obtenidas en este trabajo. La norma americana ASTM C876 (35) define estadísticamente, con una probabilidad del $90 \%$, intervalos de Ecorr que darían lugar a estados de corrosión inactiva (Ecorr > -277 mV vs SCE, punto (a) de la Figura 10) y corrosión activa (Ecorr < $-427 \mathrm{mV}$ vs SCE, punto (b) de la Figura 10). Según los datos obtenidos en este trabajo, se observó que existía una buena concordancia del límite de corrosión inactiva obtenido (punto (c) de la Figura 6, Ecorr $=-296 \mathrm{mV}$ vs SCE) y el ofrecido por la norma ASTM C876. En cambio en el caso del límite de corrosión activa, el valor que se obtuvo en el estudio fue sensiblemente inferior (punto (d) de la Figura 6, Ecorr $=-530 \mathrm{mV}$ vs SCE) al marcado por dicha norma. Esta discordancia pudo tener origen en que el número de puntos experimentales en la zona de corrosión activa que se obtuvieron en este trabajo es limitado. Además, la norma americana también contempla corrosión producida por cloruros, mientras que en este caso sólo se estudió la carbonatación de los morteros.
Figure 10 plots the Icorr values against the Ecorr values obtained in the study. American standard ASTM C876 (35) statistically defines the Ecorr values that, with $90 \%$ probability, would give rise to inactive corrosion (Ecorr > -277 mV vs SCE, point (a) on Figure 10) and active corrosion (Ecorr < $-427 m V$ vs SCE, point (b) on Figure 10). The inactive corrosion limit found in the present study (point (c) on Figure 10, Ecorr $=-296 \mathrm{mV}$ vs SCE) concurred closely with the value given in standard ASTM C876. The active corrosion limit identified, however, was appreciably lower (point (d) on Figure 10, Ecorr $=-530 \mathrm{mV}$ vs SCE) than specified in the standard. This discrepancy may be due to the short number of experimental points obtained in the active corrosion zone in the present exercise. Moreover, both chloride- and carbonation-induced corrosion are taken into account in the American standard, while the present study addressed mortar carbonation alone.

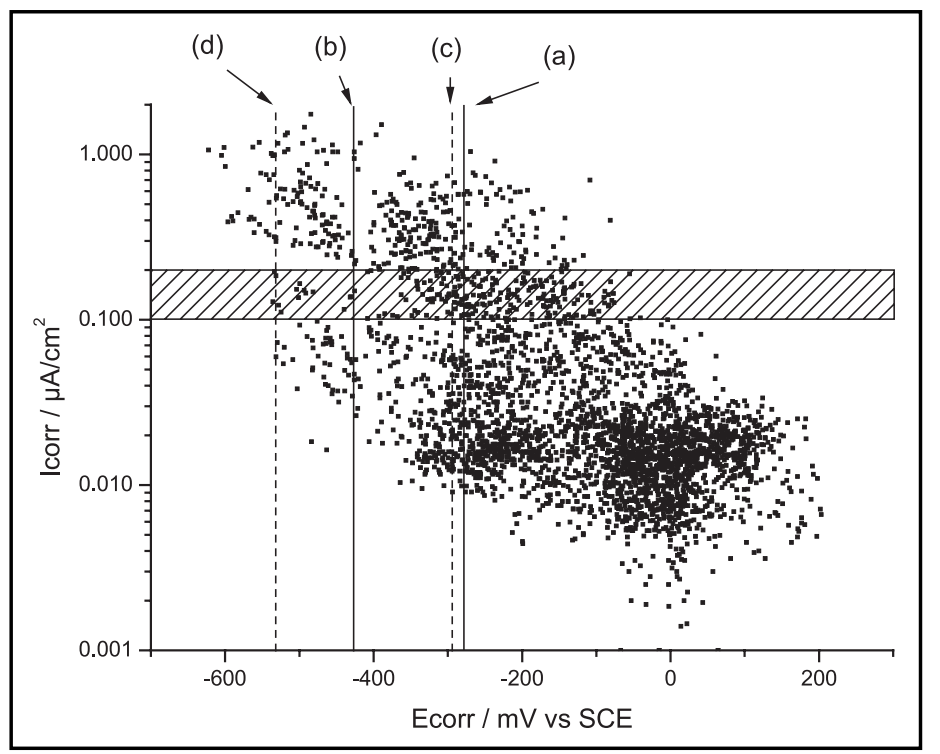

Figura 10. Relación entre Icorr y Ecorr de las medidas realizadas.

(a) y (b) son los límites de Ecorr para estados corrosión inactiva y activa, respectivamente, según ASTM C876. (c) y (d) son los límites de Ecorr obtenidos en este estudio.

Figure 10. Icorr versus Ecorr (experimental data).

(a) and (b) are the Ecorr limits for inactive and active corrosion, respectively, according to ASTM standard C876. (c) and (d) are the Ecorr limits obtained in the present study.

Con los resultados obtenidos se relacionaron los valores de Icorr con los de Ecorr a través de ecuaciones exponenciales del tipo:
The above findings were used to relate the Icorr to the Ecorr values with exponential equations of the following form: 
para distintas condiciones de medida, donde a y b son parámetros empíricos del ajuste (Tabla 1). Se eligió este modelo de ecuación ya que era la que mejor reproducía for different measuring conditions, where $a$ and $b$ are empirical fitting parameters (Table 1). This type of equation was chosen because it provided the best fit for the

Tabla 1 / Table 1

Parámetros del ajuste de los datos experimentales según la Ecuación [1]. Fitting parameters for the experimental data as per Equation [1].

\begin{tabular}{|c|c|c|c|}
\cline { 3 - 4 } \multicolumn{2}{c|}{} & $a$ & $b$ \\
\hline \multirow{4}{*}{$\begin{array}{c}\mathrm{a} / \mathrm{mc} \\
w / b\end{array}$} & 0.3 (plast) & 0.0134 & -0.0027 \\
\cline { 2 - 4 } & 0.4 (plast) & 0.0144 & -0.0023 \\
\cline { 2 - 4 } & 0.5 & 0.0169 & -0.0046 \\
\cline { 2 - 4 } & 0.7 & 0.011 & -0.0065 \\
\hline \multirow{4}{*}{$\% \mathrm{FC} 3 \mathrm{R}$} & 0 & 0.0156 & -0.0051 \\
\cline { 2 - 4 } & 5 & 0.0155 & -0.0043 \\
\cline { 2 - 4 } & 10 & 0.0148 & -0.0048 \\
\cline { 2 - 4 } & 15 & 0.0135 & -0.0054 \\
\hline \multirow{3}{*}{$\% \mathrm{HR}$} & 20 & 0.0162 & -0.0053 \\
\hline \multirow{2}{*}{$\mathrm{RH}$} & 100 & 0.0058 & -0.0066 \\
\cline { 2 - 4 } & 80 & 0.0127 & -0.005 \\
\cline { 2 - 4 } & 40 & 0.0138 & -0.0068 \\
\hline
\end{tabular}

el comportamiento de los puntos experimentales. Las tendencias obtenidas se muestran en la Figura 11. De esta forma se pudo observar con más detalle qué parámetros de los estudiados influían de forma importante en el comportamiento a la corrosión de los aceros. De la Figura 11(a) se pudo deducir que la incorporación de FC3R no modifica significativamente el comportamiento frente a la corrosión de los aceros. Se apreció que pequeñas cantidades de FC3R (de hasta el 10\%) producían experimental data. The trends observed and shown in Figure 11 clearly illustrate the impact of the various parameters on steel corrosion. It may be deduced from Figure 11(a) that the addition of FC3R did not significantly change steel corrosion performance. Small amounts of FC3R (up to 10\%) were observed to cause slight declines in Icorr compared to the response obtained for steel in the control mortar with no FC3R. By contrast, higher proportions of FC3R prompted small increases in Icorr. Figure

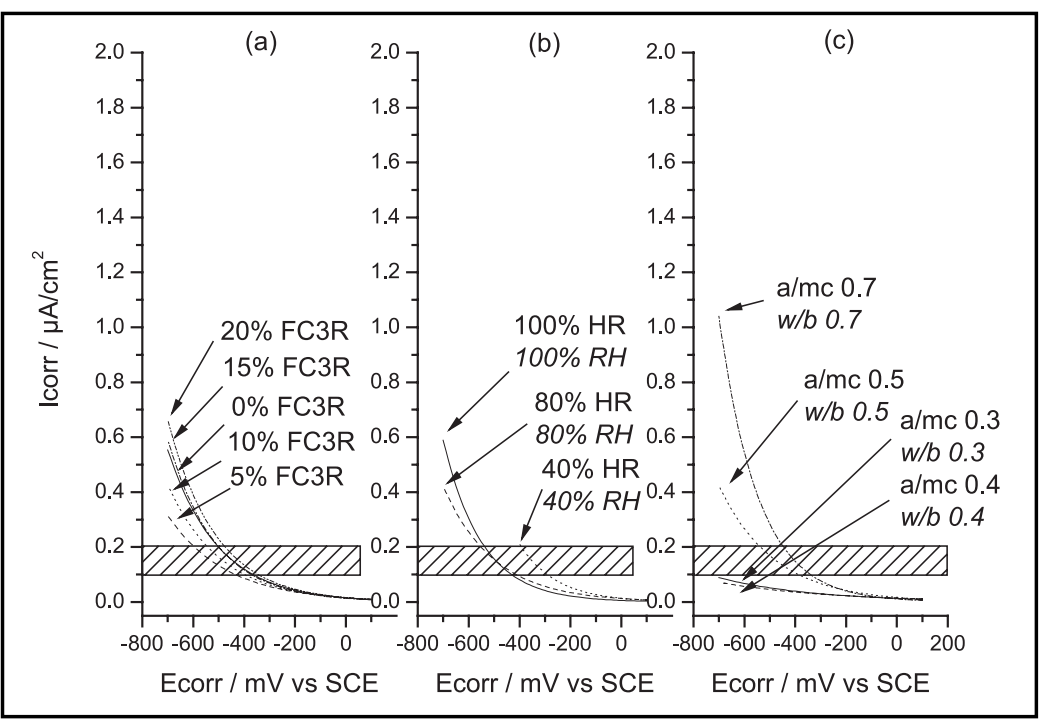

Figura 11. Ajuste de los datos experimentales según su (a) proporción de FC3R, (b) humedad relativa del ambiente, y (c) relación a/mc.

Figure 11. Fitted experimental Icorr versus Ecorr data, varying: (a) the proportion of FC3R; (b) relative humidity; and (c) the $w / b$ ratio. 
ligeros descensos de Icorr con respecto a la respuesta obtenida por los aceros del mortero control sin FC3R. Por otro lado, cantidades superiores de FC3R producían pequeños aumentos en Icorr. En la Figura 11(b) se presenta la influencia de de la HR en la respuesta de los aceros. Se pudo comprobar que en condiciones de elevada HR (80 y $100 \%)$, en las que la difusión de oxígeno hacia la superficie de los electrodos estaba más dificultada, los valores de Icorr que se obtendrían serían inferiores a los que se hallarían en condiciones de baja $\mathrm{HR}$, debido a que en este caso la entrada de oxígeno sería mucho mayor. Ahora bien, hay que considerar que para una humedad relativa del $40 \%$ se establecería un control óhmico de la pila de corrosión que limitaría el desarrollo de la corrosión. Es por ello que no se han considerado en este caso valores de Ecorr por debajo de $-400 \mathrm{mV}$. Por último, en la Figura 11 (c) se presenta la influencia de la relación a/mc que se esperaría. Se pudo comprobar que para las relaciones $\mathrm{a} / \mathrm{mc}$ bajas $(0,3$ y 0,4$)$, cuyos morteros eran mucho menos porosos (Figura 8) y por tanto más impermeables, los valores de Icorr serían claramente inferiores a los que se obtendrían con una relación a/mc de 0,5 ó 0,7 . Así pues de los tres parámetros, el que menos modificaciones introducía en los valores de Icorr era el nivel de sustitución de cemento por FC3R.

\section{CONCLUSIONES}

Se han podido extraer las siguientes conclusiones a partir de los resultados obtenidos en el presente trabajo:

- La incorporación de FC3R como sustitución parcial de cemento en cantidades de hasta el $15 \%$ no compromete la pasivación de las armaduras de acero. Este hecho se ha podido comprobar en un amplio intervalo de condiciones experimentales que comprendían relaciones $\mathrm{a} / \mathrm{mc}$ entre 0,3 y 0,7 y humedades relativas entre el 40 y el $100 \%$.

- La sustitución de cemento por FC3R ha mostrado ejercer una menor influencia en los parámetros de corrosión que otras variables como son la relación a/mc o la humedad relativa del ambiente.

- Los morteros con FC3R han presentado menor resistencia a la carbonatación y mayores niveles de corrosión como producto de la misma cuando la relación $\mathrm{a} / \mathrm{mc}$ es muy elevada $(0,7)$. Para relaciones $\mathrm{a} / \mathrm{mc}$ medias y bajas, la incorporación de FC3R no ha supuesto diferencias con el comportamiento ofrecido en los morteros de cemento Portland.

- En condiciones de exposición normales, en las que la concentración de $\mathrm{CO}_{2}$ no constituya un factor de riesgo, la utilización de FC3R en cantidades de hasta el $15 \%$ no compromete la durabilidad de la armadura. En cambio, ante concentraciones de $\mathrm{CO}_{2}$ elevadas, extra- 11(b) shows the effect of $\mathrm{RH}$ on steel response. At high $\mathrm{RH}$ (80 and 100\%), which hindered the diffusion of oxygen toward the surface of the electrodes, the Icorr values obtained would be expected to be smaller than found at low $R H$ values, where oxygen inflow would be much greater. At the same time, however, at a relative humidity of $40 \%$ the ohmic control exerted on the corrosion cell would curb corrosion. This is why Ecorr values of under $400 \mathrm{mV}$ were not considered in this case. Lastly, Figure 11 (c) shows that the effect of the $w / b$ ratio was as expected. For low $w / b$ ratios (0.3 and 0.4 ), which yielded much less porous (Figure 8 ) and consequently less permeable mortars, the Icorr values were clearly lower than obtained with $w / b$ ratios of 0.5 or 0.7 . Of the three parameters, then, the one that that affected the Icorr values the least was cement replacement by FC3R.

\section{CONCLUSIONS}

The following conclusions can be drawn from the above findings:

- The passivation of reinforcing steel is not compromised by the presence of up to $15 \%$ of FC3R in Portland cement blends. This finding was verified across a wide range of experimental conditions: $w / b$ ratios from 0.3 to 0.7 and relative humidity values from 40 to $100 \%$.

- Replacing cement with FC3R had a smaller impact on the corrosion parameters than variables such as the $w / b$ ratio or relative humidity.

- Mortars containing FC3R were less resistant to carbonation and exhibited greater carbonation-induced corrosion when the $w / b$ ratio was very high (0.7). At low and medium $w / b$ ratios, no differences were observed in the corrosion performance of these mortars compared to Portland cement mortars.

- Under normal exposure conditions, in which the $\mathrm{CO}_{2}$ concentration does not constitute a risk factor, the use of up to $15 \%$ FC3R does not compromise reinforcement durability. At high $\mathrm{CO}_{2}$ concentrations, however, the behaviour observed under accelerated carbonation 
polando el comportamiento observado en las condiciones de carbonatación acelerada usadas en este estudio, la incorporación de FC3R debería ir unida al uso de relaciones $\mathrm{a} / \mathrm{mc}$ bajas para no comprometer la durabilidad de la armadura.

\section{AGRADECIMIENTOS}

E. Zornoza agracede al Ministerio de Educación, Cultura y Deporte de España la concesión de su beca de doctorado de programa FPU (AP2002-3421). Los autores agradecen al Ministerio de Ciencia y Tecnología de España el apoyo financiero del proyecto MAT 2001-2694 y a FEDER por el apoyo ofrecido para llevar a cabo esta investigación, así como a los Dres. L. Ga Andión y C. Andrade por sus comentarios a este trabajo. conditions suggests that FC3R should be used in conjunction with low $w / b$ ratios, for otherwise reinforcement durability may be compromised.

\section{BIBLIOGRAFÍA / BIBLIOGRAPHY}

(1) Baccay, M. A., Otsuki, N., Nishida, T., Maruyama, S.: "Influence of cement type and temperature on the rate of corrosion of steel in concrete exposed to carbonation". Corrosion 62 (2006) 811-821.

(2) Pal, S. C., Mukherjee, A. S. R.: Pathak. "Corrosion behavior of reinforcement in slag concrete". ACI Materials Journal 99 (2002) $521-527$.

(3) Parrot, L. J.: "Some effects of cement and curing upon carbonation and reinforcement corrosion in concrete". Materials and Structures 29 (1996) 164-173. http://dx.doi.org/10.1007/BF02486162

(4) Parrot. L. J. "A study of carbonation-induced corrosion". Magazine of Concrete Research 46 (1994) 23-28.

(5) Batis, G., Pantazopoulou, P., Tsivilis, S., Gadogiannis, E.: "The effect of metakaolin on the corrosion behaviour of cement mortars". Cement \& Concrete Composites 27 (2005) 125-130. http://dx.doi.org/10.1016/j.cemconcomp.2004.02.041

(6) Jiang, L. H., Liu, Z. Q., Ye, Y. Q.: "Durability of concrete incorporating large volumes of low-quality fly ash". Cem. Concr. Res. 34 (2004) 1467-1469. http://dx.doi.org/10.1016/j.cemconres.2003.12.029

(7) Montemor, M. F., Cunha, M. P., Ferreira, M. G., Simoes, A. M.: "Corrosion behaviour of rebars in fly ash mortar exposed to carbon dioxide and chlorides". Cement \& Concrete Composites 24 (2002) 45-53. http://dx.doi.org/10.1016/S0958-9465(01)00025-7

(8) Payá, J., Monzó, J., Borrachero, M. V., Velázquez, S.: "Evaluation of the pozzolanic activity of fluid catalytic cracking residue (FCC). Thermogravimetric analysis studies on FCC-Portland cement pastes". Cem. Concr. Res. 33 (2003) 603-609. http://dx.doi.org/10.1016/S0008-8846(02)01026-8

(9) Payá, J., Monzó, J., Borrachero, M. V., Velázquez, S., Bonilla, M.: "Determination of the pozzolanic activity of fluid catalytic cracking residue. Thermogravimetric analysis studies on FC3R-lime pastes". Cem. Concr. Res. 33 (2003) 1085-1091. http://dx.doi.org/10.1016/S0008-8846(03)00014-0

(10) Payá, J., Monzó, J., Borrachero, M. V.: "Fluid catalytic cracking catalyst residue (FC3R). An excellent mineral by-product for improving early-strength development of cement mixtures". Cem. Concr. Res. 29 (1999) 1773-1779.http://dx.doi.org/ 10.1016/ S00088846(99)00164-7

(11) Payá, J., Monzó, J., Borrachero, M. V., Amahjour, F., Girbés, I., Velázquez, S., Ordónez, L. M.: "Advantages in the use of fly ashes in cements containing pozzolanic combustion residues: silica fume, sewage sludge ash, spent fluidized bed catalyst and rice husk ash". Journal of Chemical Technology and Biotechnology 77 (2002) 331-335. http://dx.doi.org/10.1002/jctb.583

(12) Su, N., Fang, H.-Y., Chen, Z.-H. Liu, F.-S.: "Reuse of waste catalyst from petrochemical industries for cement substitution". Cem. Concr. Res. 30 (2000) 1773-1783. http://dx.doi.org/10.1016/S0008-8846(00)00401-4

(13) Alcocel, E. G., Garces, P., Martinez, J. J., Payá, J., Andión, L. G.: "Effect of sewage sludge ash (SSA) on the mechanical performance and corrosion levels of reinforced Portland cement mortars". Mater. Construcc. 56, no 282, pp. 31-43 (2006).

(14) Blanco-Varela, M. T., Martínez-Ramírez, S., Gener, M., et al.: "Modifications induced by adding natural zeolitic pozzolans to cement paste". Mater. Construcc. 55, no 280, pp. 27-42 (2005).

(15) Chen, H.-L., Tseng, Y.-S., Hsu, K.-C.: "Spent FCC catalyst as a pozzolanic material for high-performance mortars". Cement \& Concrete Composites 26 (2004) 657-664. http://dx.doi.org/10.1016/S0958-9465(03)00048-9

(16) Wu, J.-H., Wu, W.-L., Hsu, K.-C.: "The effect of waste oil-cracking catalyst on the compressive strength of cement pastes and mortars". Cem. Concr. Res. 33 (2003) 245-253. http://dx.doi.org/10.1016/S0008-8846(02)01006-2

(17) Wu, W.-L., Wu, J.-H., Hsu, K.-C., Yen, D.-S.: "Subproducto del fraccionamiento catalítico del petróleo: características, actividad puzolánica y su efecto en las propiedades del mortero". Cemento Hormigón 850 (2003) 18-25.

(18) Hsu, K.-C., Tseng, Y.-S., Ku, F.-F., Su, N.: "Oil cracking waste catalyst as an active pozzolanic material for superplasticized mortars". Cem. Concr. Res. 31 (2001) 1815-1820. http://dx.doi.org/10.1016/S0008-8846(01)00693-7 
(19) Pacewska, B., Wilinska, I., Bukowska, M., Nocun-Wczelik, W.: "Effect of waste aluminosilicate material on cement hydration and properties of cement mortars". Cem. Concr. Res. 32 (2002) 1823-1830. http://dx.doi.org/10.1016/S0008-8846(02)00873-6

(20) Pacewska, B., Bukowska, M., Wilinska, I., Swat, M.: "Modification of the properties of concrete by a new pozzolan. A waste catalyst from the catalytic process in a fluidized bed". Cem. Concr. Res. 32 (2002) 145-152. http://dx.doi.org/10.1016/S0008-8846(01)00646-9 (21) Stern, M., Geary, A. L.: "A therical analysis of the shape of polarization curves". Journal of Electrochemical Society 104 (1957) 56. http://dx.doi.org/10.1149/1.2428473

(22) Miranda, J. M., Otero, E., Gonzalez, J. A., et al.: "Behaviour of corroded steel in a $\mathrm{Ca}(\mathrm{OH})(2)$-saturated solution and in cement mortar. Possibility of rehabilitation". Mater. Construcc. 57, n² 285, pp. 5-16 (2007).

(23) Andrade, C., González, J. A.: "Quantitavie measurements of corrosion rate of reinforcing steels embedded in concrete using polarization resistance measurements". Werkst. Korros. 29 (1978) 515. http://dx.doi.org/10.1002/maco.19780290804

(24) Anzola, E., Malave, R., Contreras, A., et al.: "Effect of steel surface conditions on reinforcing steel corrosion in concrete exposed to marine environments". Mater. Construcc. 55, no 279, pp. 17-24 (2005).

(25) Ahmed, S. F. U., Maalej, M., Paramasivam, P., Mihashi, H.: "Assessment of corrosion-induced damage and its effect of the structural behaviour of RC beams containing supplementary cementitious materials". Progress in Structural Engineering and Materials 8 (2006) 69-77. http://dx.doi.org/10.1002/pse.214

(26) Hou, J., Chung, D. D. L.: "Effect of admixtures in concrete on the corrosion resistance of steel reinforced concrete". Corrosion Science 42 (2000) 1489-1507. http://dx.doi.org/10.1016/S0010-938X(99)00134-1

(27) Dotto, J. M. R., de Abreu, A. G., Dal Molin, D. C. C., Müller., I. L.: "Influence of silica fume addition on concretes physical properties and on corrosion behaviour of reinforcement bars". Cement \& Concrete Composites 26 (2004) 31-39. http://dx.doi.org/10.1016/S09589465(02)00120-8

(28) Dinakar, P., Babu, K. G., Santhanam., M.: "Corrosion behaviour of blended cements in low and medium strength concretes". Cement \& Concrete Composites 29 (2007) 136-145. http://dx.doi.org/10.1016/j.cemconcomp.2006.10.005

(29) Güneyisi, E., Özturan, T., Gesoglu, M.: "A study on reinforcement corrosion and related properties of plain and blended cement concretes under different curing conditions". Cement \& Concrete Composites 27 (2005) 449-461. http://dx.doi.org/10.1016/j.cemconcomp.2004.05.006

(30) Yeau, K. Y., Kim, E. K.: "An experimental study on corrosion resistance of concrete with ground granulate blast-furnace slag". Cem. Concr. Res. 35 (2005) 1391-1399. http://dx.doi.org/10.1016/j.cemconres.2004.11.010

(31) Gu, P., Beaudoin, J. J.: "Obtaining effective half-cell potential measurements in reinforced concrete structures". Construction Technology Updates No. 18. Ed. National Research Council of Canada, Ottawa, 1998.

(32) Zornoza, E., Garcés, P., Monzó, J., Borrachero, M. V., Payá, J.: "Compatibility of fluid catalytic cracking catalyst residue (FC3R) with various types of cement". Advances in Cement Research 19:3 (2007) 117-124. http://dx.doi.org/10.1680/adcr.2007.19.3.117

(33) Arandigoyen, M., Álvarez, J. I.: "Pore structure and carbonation in blended lime-cement pastes". Mater. Construcc. 56, n 282, pp. 17-30 (2006).

(34) Arandigoyen, M., Álvarez, J. I.: "Carbonation process in lime pastes with different water/binder ratio". Mater. Construcc. 56, no 281, pp. 5-18 (2006).

(35) Norma Americana ASTM C876. "Standard test method for half-cell potentials of uncoated reinforcing steel in concrete". 
